\title{
Serum IL-21 levels predict HBeAg decline during rescue therapy in patients with partial response to nucleos(t)ide analogues
}

\author{
YUE LI ${ }^{1}$, CALVIN Q. PAN ${ }^{2,3}$, SHIBO JI ${ }^{1}$, GAIQIN YAN ${ }^{4}$, JUN CHENG $^{4}$, SHUNAI LIU $^{4}$ and HUICHUN XING ${ }^{1}$ \\ ${ }^{1}$ Department of Hepatology Division $3 ;{ }^{2}$ Center of Liver Diseases, Beijing Ditan Hospital, \\ Capital Medical University, Beijing 100015, P.R. China; ${ }^{3}$ Division of Gastroenterology and Hepatology, NYU Langone Health, \\ New York University School of Medicine, New York City, NY 10016, USA; ${ }^{4}$ Beijing Key Laboratory of Emerging Infectious \\ Diseases, Institute of Infectious Diseases, Beijing Ditan Hospital, Capital Medical University, Beijing 100015, P.R. China
}

Received September 11, 2019; Accepted October 25, 2020

DOI: $10.3892 / \mathrm{etm} .2021 .9648$

\begin{abstract}
To investigate whether IL-21 levels predict treatment outcomes of salvage therapy among patients with suboptimal response (SOR) to nucleos(t)ide analogues (NAs), serum IL-21 levels were measured in a prospective cohort of hepatitis $\mathrm{B}$ e antigen ( $\mathrm{HBeAg}$ )-positive patients with SOR to antiviral therapy. The patients switched therapy to entecavir (ETV) with or without adefovir (ADV) for 104 weeks. IL-21 levels at treatment week 12 in patients who achieved $\mathrm{HBeAg}$ loss with undetectable levels of hepatitis B virus (HBV)-DNA at week 104 were the primary endpoint and the results were compared with those of corresponding patients without such an endpoint. Furthermore, IL-21 levels at treatment week 12 in patients who achieved an HBeAg-level decline at week 104 were assessed as the secondary endpoint. Among 24 enrolled patients with SOR to ADV ( $n=21)$, telbivudine $(n=2)$ or ETV $(\mathrm{n}=1)$, the median (10-90th percentile) levels of HBeAg, HBV-DNA and ALT at baseline were $2.7(0.2-3.1) \log _{10}$
\end{abstract}

Correspondence to: Professor Huichun Xing, Department of Hepatology Division 3, Beijing Ditan Hospital, Capital Medical University, 8 Jingshundong Street, Chaoyang, Beijing 100015, P.R. China

E-mail: hchxing@ccmu.edu.com

Professor Shunai Liu, Beijing Key Laboratory of Emerging Infectious Diseases, Institute of Infectious Diseases, Beijing Ditan Hospital, Capital Medical University, 8 Jingshundong Street, Chaoyang, Beijing 100015, P.R. China

E-mail: liusa1031@sina.com

Abbreviations: ADV, adefovir dipivoxil; $\mathrm{CHB}$, chronic hepatitis $\mathrm{B}$; CXCR5, chemokine C-X-C motif receptor 5; ETV, entecavir; EVR, early virological response; HBV, hepatitis B virus; LdT, telbivudine; NAFLD, nonalcoholic fatty liver disease; NAs, nucleos(t)ide analogues; NED, no HBeAg level decline; NCR, no complete response; NK, natural killer; NVR, no virological response; Tfh, follicular T helper; SOR, suboptimal response

Key words: hepatitis B virus, IL-21, antiviral therapy, suboptimal response, outcome predictors
S/CO, $5.2(3.5-7.5) \log _{10} \mathrm{IU} / \mathrm{ml}$ and 0.9 (0.5-3.1) upper limit of normal, respectively. Comparison of the patients with and without $\mathrm{HBeAg}$ loss at week 104 indicated that their mean IL-21 levels did not significantly differ at week $12(63.0 \pm 14.4$ vs. $55.9 \pm 10.5 \mathrm{pg} / \mathrm{ml} ; \mathrm{P}=0.26)$. In the secondary endpoint analyses of patients with and without $\mathrm{HBeAg}$ level decline, the elevated levels of IL-21 at the first 12 weeks were significantly higher in the decline group $(15.6 \pm 8.3$ vs. $3.1 \pm 13.2 \mathrm{pg} / \mathrm{ml}$; $\mathrm{P}=0.03)$. Following adjustment for confounding factors, the elevated levels of IL-21 from baseline to week 12 independently predicted an $\mathrm{HBeAg}$ level decline at week 104 (odds ratio=1.137, $\left.\mathrm{R}^{2}=0.23 ; \mathrm{P}=0.047\right)$. In conclusion, the serum IL-21 levels at the first 12 weeks during the salvage therapy independently predicted $\mathrm{HBeAg}$ level decline at treatment week 104 in patients with SOR to NAs (ClinicalTrials.gov identifier: NCT01829685; date of registration, April 2013).

\section{Introduction}

Chronic hepatitis B (CHB) mainly comprises a chronic immune-mediated inflammatory injury to the liver as a result of persistent hepatitis B virus (HBV) infection (1). Therefore, effective antiviral therapy is crucial for viral clearance and the improvement of disease outcomes. The current goals of treatment are to reduce the occurrence of liver cancer and disease progression to cirrhosis (2). Several segregating markers have been adopted in the clinical setting to measure the treatment response of hepatitis B e antigen ( $\mathrm{HBeAg}$ )-positive patients who have been receiving antiviral therapy. The markers include an HBV-DNA decline to undetectable levels, transaminase normalization, $\mathrm{HBeAg}$ and hepatitis B surface antigen (HBsAg) level decline following treatment (2).

IL-21 is a type I cytokine that shares the common $\gamma$-chain receptor subunit with the IL-2, IL-4, IL-7, IL-9 and IL-15 cytokines. It is produced by activated $\mathrm{CD} 4^{+} \mathrm{T}$ cells, particularly follicular $\mathrm{T}$ helper (Tfh) cells, $\mathrm{T}$ helper 17 cells and activated natural killer (NK) T cells (3-6). IL-21 is considered a bridge between innate and adaptive immunity with immune-enhancing and immune-regulatory effects on B-, $\mathrm{T}$ - and NK-cell responses $(7,8)$. IL-21 is derived from CD4 ${ }^{+}$ $\mathrm{T}$ cells and acts as an effective intermediate cytokine for the optimal generation of specific $\mathrm{CD} 8^{+} \mathrm{T}$ - and $\mathrm{B}$-cell responses 
in the process of HBV infection. The expression of $1 \mathrm{~L}-21$ is closely associated with HBV clearance (9-11), clearance of HBV antigens (12-14), occurrence of HBV-associated liver cirrhosis, liver failure and liver cancer $(15,16)$. During the follow-up period of treatment-naïve $\mathrm{HBeAg-negative} \mathrm{patients}$ with raised alanine aminotransferase (ALT), the patients undergoing spontaneous HBsAg seroconversion exhibited higher serum levels of IL-21 compared with those of the non-convertors (17). A previous study in HBeAg-positive CHB patients undergoing telbivudine monotherapy indicated that serum IL-21 levels at treatment week 12 were significantly higher in patients who achieved HBeAg seroconversion. This marker was able to independently predict $\mathrm{HBeAg}$ seroconversion in the first year of treatment (12). In patients with coexistence of $\mathrm{HBeAg}$-positive $\mathrm{CHB}$ and nonalcoholic fatty liver disease (NAFLD) receiving entecavir monotherapy, the elevation of IL-21 levels from baseline to week 12 was significantly higher in the early (24 weeks) virological response (EVR) group and the elevated levels of IL-21 at treatment week 12 were able to predict EVR in $\mathrm{CHB}^{+}$NAFLD patients (18).

The virological response on nucleos $(t)$ ide analogue (NA) therapy is associated with the dynamic virus-host immune interaction and the antiviral agents selected. Particularly in resource-constrained settings, suboptimal virological response (SOR), defined as detectable HBV DNA after 24-48 weeks of NA monotherapy without resistance mutation, frequently occurs (19). Patients with SOR on NA monotherapy require an optimized strategy as salvage therapy.

However, to the best of our knowledge, the association between the dynamic changes of IL-21 levels and the treatment outcomes among patients with SOR to NAs who receive salvage therapy has not been previously reported. Therefore, the present study aimed to investigate whether IL-21 level changes at treatment week 12 in these patients are able to predict $\mathrm{HBeAg}$ loss or decline at week 104 of salvage therapy.

The major aims of the present study were the following: i) To investigate the dynamic changes of IL-21 levels during salvage therapy in patients with SOR; and ii) to assess the association between IL-21 levels and treatment outcomes of salvage therapy in patients with SOR.

\section{Subjects and methods}

Study subjects. A total of 24 patients with CHB who participated in a multicenter randomized controlled clinical trial (ClinicalTrials.gov identifier: NCT01829685) for the treatment of SOR to NAs at Beijing Ditan Hospital, Capital Medical University (Beijing, China) were recruited for the present study between April 2011 and April 2014. Additional informed consent was obtained from these patients for the use of their clinical data, for specimen collection and for the measurement of IL-21 levels. The inclusion criteria were as follows: $\mathrm{CHB}$ with HBeAg-positive status, HBV-DNA levels >1,000 IU/ml following 24 weeks of monotherapy with telbivudine (LdT) or entecavir (ETV) at $0.5 \mathrm{mg}$ daily or 48 weeks of adefovir dipivoxil (ADV) monotherapy and undetected antiviral resistant mutants. The patients were excluded from the study if they had any of the following conditions: Positivity for HCV, HDV or HIV, history of alcohol consumption (alcohol consumption $>20 \mathrm{~g}$ per day for females or $>30 \mathrm{~g}$ per day for males), hepatic decompensation, presence of other liver diseases or severe systemic diseases or administration of immunomodulator therapy within 6 months.

Among the 24 enrolled subjects, 21 were on ADV, 2 on LdT and 1 on ETV therapy at $0.5 \mathrm{mg}$ daily. These patients randomly received one of the three salvage oral regimens: ETV at $1.0 \mathrm{mg}$ daily, ETV at $1.0 \mathrm{mg}$ plus ADV at $10 \mathrm{mg}$ daily or ETV at $0.5 \mathrm{mg}$ plus ADV at $10 \mathrm{mg}$ daily for 104 weeks. During the baseline and follow-up visits at weeks 12, 24, 36, $52,64,76,88$ and 104, $23 \mathrm{ml}$ of serum was obtained from each subject and stored at $-80^{\circ} \mathrm{C}$ for measurement of cytokine concentrations. In addition, blood samples were collected for biochemical, serological and HBV-DNA assays.

At week 104 of salvage therapy, SOR patients were classified into either the complete response (CR) group if they achieved HBeAg loss and undetectable levels of serum HBV-DNA (the lower limit of detection was $20 \mathrm{IU} / \mathrm{ml}$ ) or the no complete response (NCR) group if they remained $\mathrm{HBeAg}$-positive independent of HBV-DNA levels. In the NCR group, the patients were further divided into two subgroups of virological response (VR) compared with no virological response (NVR) based on their levels of viremia (undetectable vs. detectable). For secondary assessment, the SOR patients were classified into either a $\mathrm{HBeAg}$ level decline (ED) group if the decline level of serum $\mathrm{HBeAg}\left(\log _{10} \mathrm{~S} / \mathrm{CO}\right)$ from baseline to week 104 was $50 \%$ or more or a no $\mathrm{HBeAg}$ level decline (NED) group if the decline level did not reach $50 \%$.

Association of outcome measures with IL-21 levels. The primary endpoint was the difference in IL-21 levels between the CR and NCR groups at week 12. The serum IL-21 levels and other baseline markers were assessed for predicting complete response. Subsequently, within the NCR group, the IL-21 levels in the two subgroups of VR vs. NVR were compared. Secondary endpoints included the comparison of IL-21 levels between the ED and NED groups and the dynamic changes of IL-21 levels from baseline to week 104.

Laboratory tests and assays. The liver function of the patients was measured using the Hitachi 7600-020 full-automatic biochemical analyzer by rate essay. HBV serological markers were detected using the ARCHITECT i2000SR full-automatic immunoassay analyzer (Abbott Laboratories) by chemiluminescence microparticle immunoassay. HBV viral load was quantified using the Roche Lightcycler ${ }^{\circledR} 480$ system by real-time quantitative $\mathrm{PCR}$, which had a detection limit of $20 \mathrm{IU} / \mathrm{ml}$. The concentrations of serum IL-21 were measured in duplicate using a commercial human IL-21 ELISA kit (Mabtech) by the double antibody sandwich method. The units of the IL-21 concentration were $\mathrm{pg} / \mathrm{ml}$.

Statistical analysis. Data analysis was conducted using SPSS 24.0 (IBM Corp.). Continuous data were expressed as either the median (10-90th percentile) or the mean \pm standard deviation according to whether the data satisfied the assumptions of normal distribution. The independent-samples t-test (unpaired), the Mann-Whitney U-test and the Chi-square test were used for comparisons between two groups. One-way or two-way repeated-measures ANOVA was used for comparisons of repeated sample data. One-way ANOVA 
was used for univariate analysis. When the spherical data distribution assumption was not satisfied, a multivariate test or Greenhouse-Geisser correction were adopted. Bonferroni's post-hoc test was used for multiple comparisons. Multi-way ANOVA and logistic regression analysis were used to assess the predictive value of each variable regarding the treatment response. Receiver operating characteristic curves were constructed to identify the optimal cut-off values for predicting treatment outcomes and for calculating the sensitivity and specificity of the predictions using these values. Spearman's rank order correlation coefficient was determined to assess the correlation. All statistical analyses were based on two-tailed hypothesis tests and $\mathrm{P}<0.05$ was considered to indicate statistical significance.

\section{Results}

Baseline characteristics. Following approval by the Institutional Review Board (IRB) of Beijing Ditan Hospital, Capital Medical University (Beijing, China; IRB no. NFEC-201011-K1), 24 subjects consented and were enrolled in the study between April 2011 and April 2014. The subjects of the SOR group included 21 patients on ADV, 2 on LdT and 1 on ETV at $0.5 \mathrm{mg}$ daily. The subjects included 15 males and 9 females with a median age of 30.5 (range, 23.5-51.0) years. The median levels of HBeAg and HBV DNA were 2.7 (0.2-3.1) $\log _{10} \mathrm{~S} / \mathrm{CO}$ and $5.2(3.5-7.5) \log _{10} \mathrm{IU} / \mathrm{ml}$, respectively. The baseline characteristics of the patients are provided in Table I.

Changes in virological markers and IL-21 concentration during treatment. The changes in the serum HBV-DNA, HBeAg and ALT levels in the patients who received salvage treatment for 104 weeks are presented in Fig. 1A. Serum HBV-DNA levels declined as the salvage treatment continued $(\mathrm{P}<0.05)$ and the decline of the HBV-DNA levels during the initial 12 weeks of treatment was the most significant (baseline, $5.3 \pm 1.4 \log _{10} \mathrm{IU} / \mathrm{ml}$ vs. week $\left.12,2.6 \pm 1.0 \log _{10} \mathrm{IU} / \mathrm{ml} ; \mathrm{P}<0.001\right)$. At week 104, 15 patients had undetectable levels of serum HBV-DNA. In addition to the decline in serum HBV-DNA levels, serum HBeAg levels declined accordingly $(\mathrm{P}=0.037)$, particularly from baseline [2.7 (0.2-3.1) $\left.\log _{10} \mathrm{~S} / \mathrm{CO}\right]$ to week 12 [2.3 (0.0-3.0) $\left.\log _{10} \mathrm{~S} / \mathrm{CO}\right](\mathrm{P}=0.01)$ and HBeAg loss occurred in 4 patients at week 104. Mean ALT levels returned to normal by week 24 .

Repeated-measures analysis of the IL-21 levels indicated that the serum IL-21 levels were elevated from baseline to week $36(\mathrm{P}=0.007)$ and subsequently, they were gradually reduced to reach the baseline level again by week 104 (Fig. 1B). The mean IL-21 concentration at week $24(65.4 \pm 16.4 \mathrm{pg} / \mathrm{ml})$ and week $36(67.1 \pm 18.5 \mathrm{pg} / \mathrm{ml})$ was significantly higher than that at the baseline $(50.4 \pm 12.2 \mathrm{pg} / \mathrm{ml} ; \mathrm{P}=0.037$ and 0.047 , respectively). The serum IL-21 concentration exhibited the most obvious increase during the initial 12-week period of salvage treatment, which was consistent with the period when serum HBV-DNA levels exhibited the greatest reduction.

Spearman's correlation analysis indicated that serum IL-21 concentrations may exhibit a moderate negative correlation with $\mathrm{HBeAg}$ levels $\left(\log _{10} \mathrm{~S} / \mathrm{CO}\right)$ at baseline $\left(\mathrm{r}_{\mathrm{s}}=-0.386\right.$; $\mathrm{P}=0.062)$ and at week $12\left(\mathrm{r}_{\mathrm{s}}=-0.392 ; \mathrm{P}=0.058\right)$ (Fig. $\left.\mathrm{S} 1\right)$ However, no significant correlation was noted between serum
IL-21 and serum ALT levels, or between serum IL-21 and serum HBV DNA levels at any of the time-points assessed.

Association between IL-21 concentration and treatment response. Based on the treatment outcomes at week 104, patients with SOR under salvage treatment were divided into the two following groups: CR $(n=4)$ and NCR $(n=20)$. The latter included two subgroups: VR $(n=11)$ and NVR $(n=9)$. No significant difference in gender, age, initial antiviral therapy and salvage regimens was identified between the $\mathrm{CR}$ and the NCR groups, as well as between the VR and the NVR groups. The baseline characteristics of these groups are summarized in Table I. The changes in serum IL-21 and HBV-DNA levels of CR and NCR groups over 104 weeks of treatment are presented in Fig. 2A and B. Although IL-21 levels appeared to be higher in the CR group compared with those in the NCR group from weeks 12 to 76, the differences exhibited no statistical significance at any of the time-points of investigation. HBV-DNA levels were significantly lower in the CR group compared with those in the NCR group at baseline $(\mathrm{P}=0.032)$, but there were no significant differences at other time-points.

Using univariate analysis, the influence of certain parameters, including age, gender, initial antiviral therapy, salvage regimens, serum HBV-DNA levels, serum ALT levels, serum HBeAg levels and serum IL-21 concentrations on the achievement of complete response was determined (Table II). No significant effect on the treatment response was noted with regard to the use of the different salvage regimens. Furthermore, the serum IL-21 levels at week 12 did not differ between the $\mathrm{CR}$ and the NCR groups $(63.0 \pm 14.4$ vs. $55.9 \pm 10.5 \mathrm{pg} / \mathrm{ml}$; $\mathrm{P}=0.26$ ). All variables with a $\mathrm{P}<0.15$ were included in the multivariate analysis. The variables with the strongest predictive value regarding $\mathrm{CR}$ included the $\mathrm{HBeAg}$ levels at baseline $\left(\mathrm{R}^{2}=0.25\right)$ and the HBV-DNA levels at baseline $\left(\mathrm{R}^{2}=0.16\right)$. Logistic regression analysis demonstrated that the influence of baseline HBV-DNA on CR was not significant $(\mathrm{P}=0.075)$. Following adjustment for the confounding factor (baseline HBV-DNA), the independent effect of baseline HBeAg levels became insignificant $(\mathrm{P}=0.110$; Table $\mathrm{SI})$.

Serum IL-21 levels appeared to be higher in the VR group compared with those in the NVR group from baseline to week 36, but the differences were not significant. Serum IL-21 levels at week 12 did not differ between the VR and NVR groups (58.4 \pm 12.2 vs. $52.9 \pm 7.6 \mathrm{pg} / \mathrm{ml} ; \mathrm{P}=0.26)$. However, the HBV-DNA levels were significantly lower in the VR than those in the NVR group at week 12 (1.9 \pm 0.6 vs. $\left.3.6 \pm 0.6 \log _{10} \mathrm{IU} / \mathrm{ml} ; \mathrm{P}<0.001\right)$.

Predictors of serum HBeAg level decline on salvage therapy. The decline of HBeAg levels at week 104 was present in 7 patients of the ED group, and absent in 17 patients of the NED group. In the ED group, the mean HBeAg level declined remarkably from $1.63 \pm 1.34$ to $0.06 \pm 0.49 \log _{10} \mathrm{~S} / \mathrm{CO}$ over 104 weeks of salvage therapy $(\mathrm{P}=0.013)$. Furthermore, four of these patients achieved HBeAg loss over 104 weeks. In addition, the changes in the median HBeAg levels in the NED group ranged from $2.73(0.87-3.10)$ to $1.98(0.70-2.97)$ $\log _{10} \mathrm{~S} / \mathrm{CO}$ and none of the cases exhibited any HBeAg loss (Fig. 3A). At week 104, the proportion of HBeAg loss in the ED group was significantly higher than that in the NED group (57.1\% vs. $0 ; \mathrm{P}=0.003)$. 
Table I. Baseline clinical characteristics of the study subjects assigned to different groups.

\begin{tabular}{|c|c|c|c|c|c|}
\hline Item & $\operatorname{SOR}(n=24)$ & $\mathrm{CR}(\mathrm{n}=4)$ & $\operatorname{NCR}(n=20)$ & $\operatorname{VR}(\mathrm{n}=11)$ & $\operatorname{NVR}(n=9)$ \\
\hline Gender $(\mathrm{M} / \mathrm{F})$ & $15 / 9$ & $2 / 2$ & $13 / 7$ & $5 / 6$ & $8 / 1$ \\
\hline Age (years) & $30.5(23.5-51.0)$ & $34.0(30.0-40.5)$ & $29.0(23.1-55.8)$ & $28.0(20.6-58.6)$ & $32.0(25.0-42.6)$ \\
\hline $\begin{array}{l}\text { Initial antiviral therapy } \\
\text { (ADV/LdT/ETV) }\end{array}$ & $21 / 2 / 1$ & $3 / 1 / 0$ & $18 / 1 / 1$ & $11 / 0 / 0$ & $7 / 1 / 1$ \\
\hline Salvage regimen $(\mathrm{A} / \mathrm{B} / \mathrm{C})^{\mathrm{a}}$ & $4 / 9 / 11$ & $0 / 2 / 2$ & $4 / 7 / 9$ & $2 / 4 / 5$ & $2 / 3 / 4$ \\
\hline HBV-DNA $\left(\log _{10} \mathrm{IU} / \mathrm{ml}\right)$ & $5.2(3.5-7.5)$ & $3.8(3.6-4.4)$ & $5.3(3.5-7.6)$ & $5.3(3.6-7.8)$ & $6.0(3.4-7.5)$ \\
\hline ALT (ULN) & $0.9(0.5-3.1)$ & $1.5(0.6-2.4)$ & $0.8(0.4-3.1)$ & $0.7(0.3-3.4)$ & $0.8(0.6-2.7)$ \\
\hline TBil $(\mu \mathrm{mol} / \mathrm{l})$ & $11.8(6.9-20.5)$ & $13.1(8.6-14.7)$ & $11.2(6.3-22.8)$ & $12.2(6.6-30.2)$ & $10.2(5.3-18.8)$ \\
\hline $\begin{array}{l}\text { HBsAg } \\
\left(\log _{10} \mathrm{IU} / \mathrm{ml}\right)\end{array}$ & $4.3(3.1-4.8)$ & $3.4(1.9-4.2)$ & $4.3(3.3-4.8)$ & $3.8(3.3-4.5)$ & $4.6(4.4-4.9)$ \\
\hline $\begin{array}{l}\mathrm{HBeAg} \\
\left(\log _{10} \mathrm{~S} / \mathrm{CO}\right)\end{array}$ & $2.7(0.2-3.1)$ & $0.5(0.04-2.4)$ & $2.7(1.1-3.1)$ & $2.3(0.3-2.9)$ & $2.9(2.8-3.1)$ \\
\hline
\end{tabular}

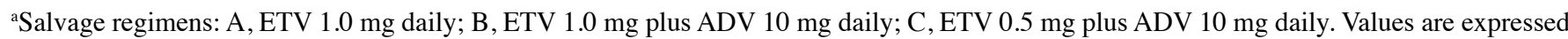
as the median (10-90\% percentile). No significant difference in gender, age, initial antiviral therapy and salvage regimens was obtained between the CR and the NCR groups, as well as between the VR and the NVR groups. Groups: SOR, HBeAg-positive CHB patients with suboptimal response to nucleos(t)ide analogues; CR, patients with HBeAg loss and HBV-DNA undetectable at week 104; NCR, patients with HBeAg-positive status at week 104; VR, patients with HBV-DNA undetectable and HBeAg-positive status at week 104; NVR, patients with HBV-DNA detectable and HBeAg-positive status at week 104. M, male; F, female; ADV, adefovir dipivoxil; LdT, telbivudine; ETV, entecavir; ALT, alanine aminotransferase; ULN, upper limit of normal; TBil, total serum bilirubin; HBsAg, hepatitis B surface antigen; HBeAg, hepatitis B e antigen.

A

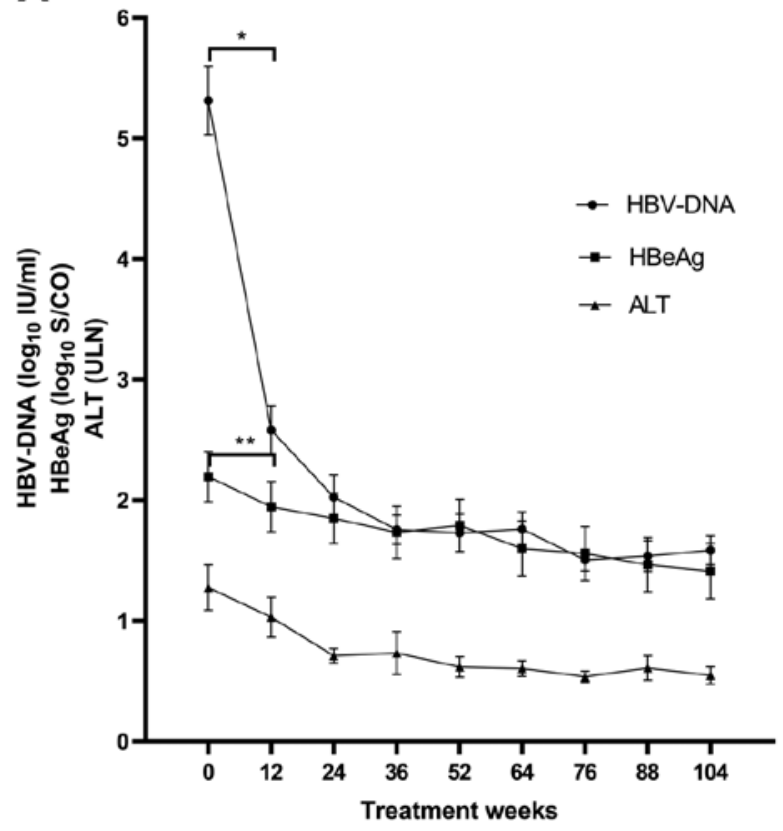

B

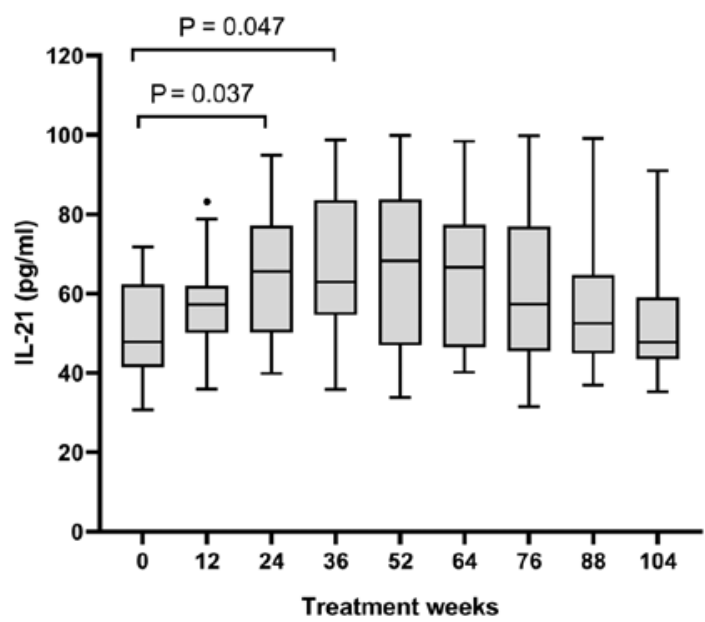

Figure 1. Changes in HBV virological markers and IL-21 concentration. (A) Comparison of the changes in HBV-DNA, HBeAg and ALT levels over 104 weeks of salvage therapy in $24 \mathrm{HBeAg}$-positive $\mathrm{CHB}$ patients with suboptimal response to nucleos(t)ide analogues. ${ }^{*} \mathrm{P}<0.001$ and ${ }^{* * *} \mathrm{P}=0.01$. (B) Serum IL-21 concentration (median, 25-75th percentile, range) over 104 weeks of salvage therapy. The dot indicates an outlier; HBV, hepatitis B virus; ALT, alanine aminotransferase; ULN, upper limit of normal; $\mathrm{HBeAg}$, hepatitis B e antigen.

Repeated-measures analysis indicated that serum IL-21 levels were elevated from baseline to week 36 and subsequently, they decreased gradually until week 104 in both the ED and the NED groups (Fig. 3B). Although the difference in mean IL-21 levels between the ED and the NED groups at week 12 was not statistically significant, the increase of serum IL-21 levels from baseline to week 12 (IL-21 level at week 12 minus IL-21 level at baseline) was higher in the ED group than that in the NED group $(15.6 \pm 8.3$ vs. $3.1 \pm 13.2 \mathrm{pg} / \mathrm{ml}$; $\mathrm{P}=0.03)$. When compared to the NED group, the HBV-DNA 
A

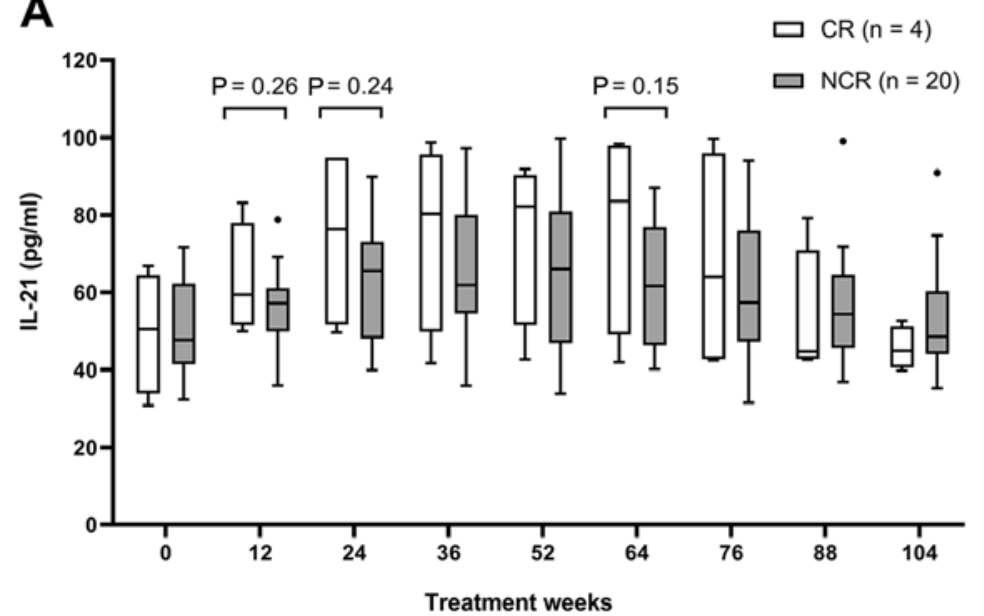

B

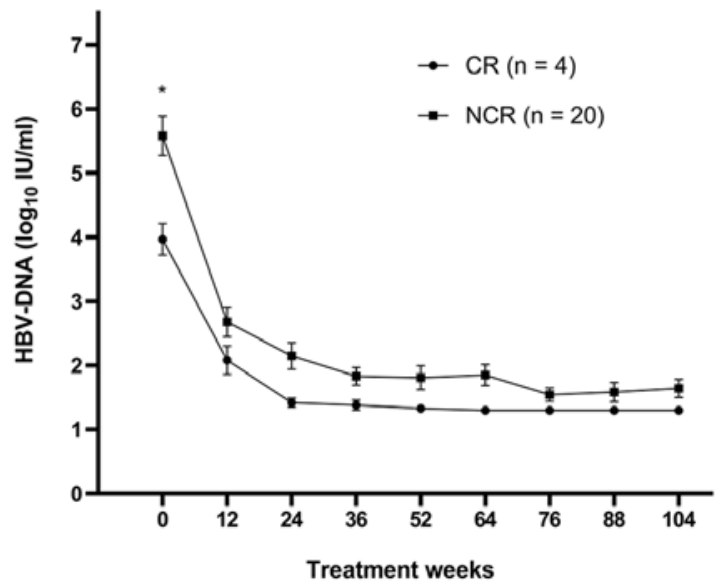

Figure 2. Association between treatment response and IL-21 concentration. (A) Comparison of the serum IL-21 concentration (median, 25-75th percentile, range) during 104 weeks of salvage therapy in the CR and NCR groups. (B) Comparison of the HBV-DNA levels during 104 weeks of salvage therapy in the CR and NCR groups. * P<0.05 vs. CR. Groups; CR, patients with HBeAg loss and HBV-DNA undetectable at week 104; The dots indicate outliers; NCR, patients with $\mathrm{HBeAg}$-positive status at week 104. NCR, no complete response; HBV, hepatitis B virus; HBeAg, hepatitis B e antigen.
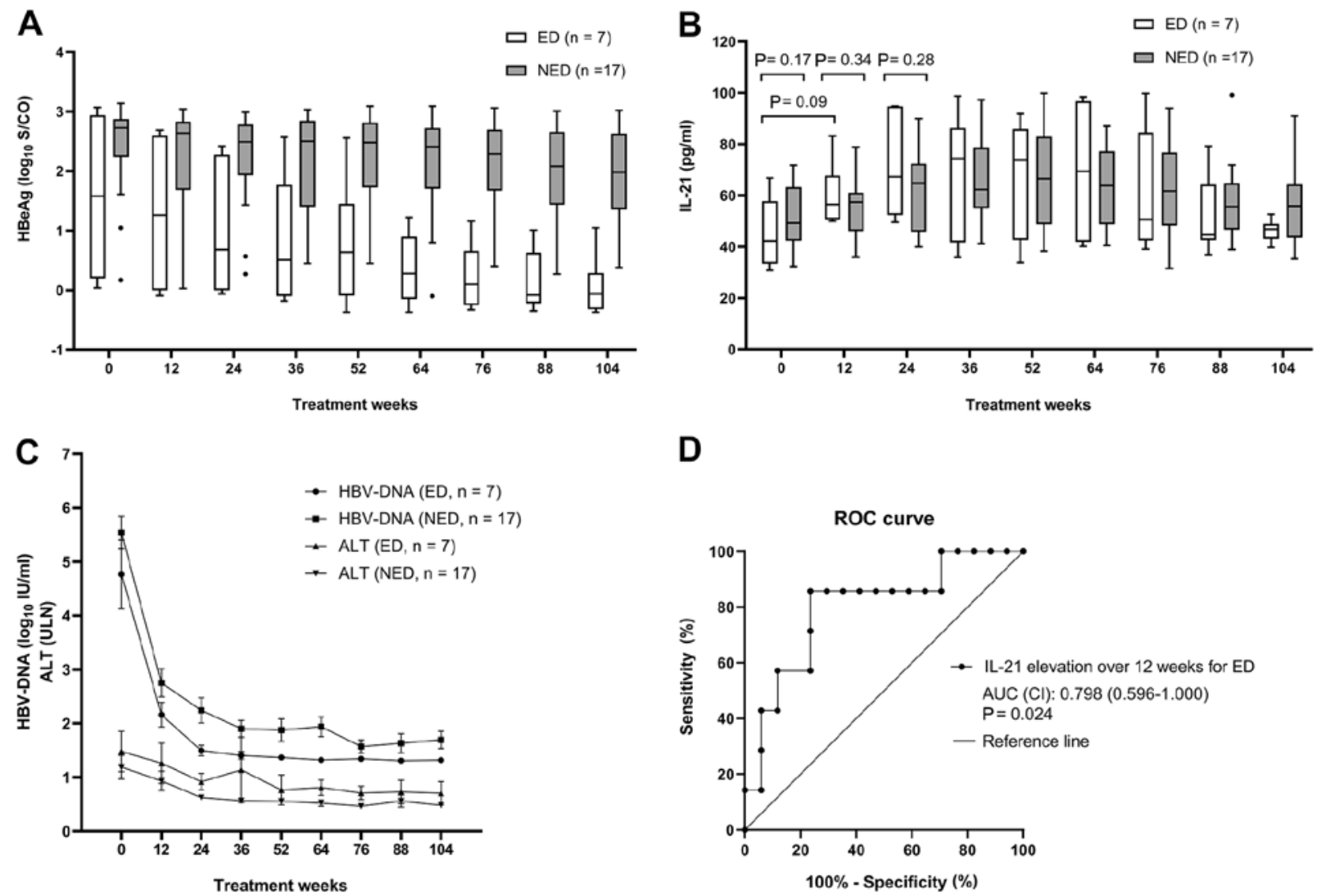

Figure 3. Prediction of serum HBeAg level decline. (A) Comparison of the serum HBeAg levels (median, 25-75th percentile, range) during 104 weeks of salvage therapy in the ED and NED groups. (B) Comparison of the serum IL-21 concentrations (median, 25-75th percentile, range) during 104 weeks of salvage therapy in the ED and NED groups. (C) Comparison of the serum HBV-DNA and ALT levels during 104 weeks of salvage therapy in the ED and NED groups. (D) ROC curve indicating the influence of the elevated levels of IL-21 over the initial 12 weeks of treatment on the probability of HBeAg decline during 104 weeks of salvage therapy. An AUC of 1.0 is indicative of a maximum diagnostic value, whereas an AUC $<0.5$ is insufficient. Groups: ED, patients with a decline in the serum level of $\mathrm{HBeAg}\left(\log _{10} \mathrm{~S} / \mathrm{CO}\right)$ from baseline to week 104 by $\geq 50 \%$; NED, patients with a decline in the serum level of $\mathrm{HBeAg}\left(\log _{10} \mathrm{~S} / \mathrm{CO}\right)$ from baseline to week 104 by $<50 \%$. NED, no HBeAg level decline. The dots indicate outlier; ROC, receiver operating characteristic; AUC, area under the curve; HBV, hepatitis B virus; ALT, alanine aminotransferase; ULN, upper limit of normal; HBeAg, hepatitis B e antigen.

levels appeared to be lower in the ED group and the ALT levels appeared to be higher; however, none of these differences were significant (Fig. 3C).
Univariate analysis was used to examine the influence of age, gender (male vs. female), initial antiviral therapy, salvage regimen, serum HBV-DNA levels, serum ALT levels, serum 
Table II. Univariate analysis of factors possibly associated with HBeAg loss.

\begin{tabular}{|c|c|c|c|}
\hline Variable/treatment week & $\mathrm{CR}(\mathrm{n}=4)$ & $\operatorname{NCR}(n=20)$ & P-value \\
\hline Age $(\text { years })^{\mathrm{a}}$ & $34.0(30.0-40.5)$ & $29.0(23.1-55.8)$ & 0.347 \\
\hline Male sex $(n, \%)^{b}$ & $2(50)$ & $13(65)$ & 0.615 \\
\hline Initial antiviral therapy $(\mathrm{ADV} / \mathrm{LdT} / \mathrm{ETV})^{\mathrm{b}}$ & $3 / 1 / 0$ & $18 / 1 / 1$ & 0.437 \\
\hline Salvage regimen $(\mathrm{A} / \mathrm{B} / \mathrm{C})^{\mathrm{b}, \mathrm{c}}$ & $0 / 2 / 2$ & $4 / 7 / 9$ & 1.000 \\
\hline \multicolumn{4}{|l|}{ HBV-DNA $\left(\log _{10} \mathrm{IU} / \mathrm{ml}\right)^{\mathrm{d}}$} \\
\hline 0 & $3.8(3.6-4.4)$ & $5.3(3.5-7.6)$ & 0.032 \\
\hline 12 & $2.1(1.5-2.5)$ & $2.9(1.3-4.1)$ & 0.276 \\
\hline 24 & $1.4(1.3-1.5)$ & $2.0(1.3-3.4)$ & 0.137 \\
\hline \multicolumn{4}{|l|}{$\operatorname{ALT}(\mathrm{ULN})^{\mathrm{a}}$} \\
\hline 0 & $1.5(0.6-2.4)$ & $0.8(0.4-3.1)$ & 0.477 \\
\hline 12 & $1.3(0.5-2.8)$ & $0.8(0.4-1.9)$ & 0.157 \\
\hline 24 & $0.8(0.5-1.4)$ & $0.6(0.4-1.1)$ & 0.273 \\
\hline Baseline $\mathrm{HBeAg}\left(\log _{10} \mathrm{~S} / \mathrm{CO}\right)^{\mathrm{a}}$ & $0.5(0.04-2.4)$ & $2.7(1.1-3.1)$ & 0.135 \\
\hline \multicolumn{4}{|l|}{$\mathrm{IL}-21(\mathrm{pg} / \mathrm{ml})^{\mathrm{d}}$} \\
\hline 0 & $49.6 \pm 15.9$ & $50.5 \pm 11.9$ & 0.900 \\
\hline 12 & $63.0 \pm 14.4$ & $55.9 \pm 10.5$ & 0.262 \\
\hline 24 & $74.3 \pm 23.9$ & $63.6 \pm 14.7$ & 0.243 \\
\hline $12-0^{\mathrm{e}}$ & $13.3 \pm 9.8$ & $5.4 \pm 13.5$ & 0.282 \\
\hline
\end{tabular}

Values are expressed as the median and $10-90 \%$ percentile or the mean \pm standard deviation unless otherwise indicated. ${ }^{\mathrm{a}} \mathrm{Mann}-\mathrm{Whitney} \mathrm{U}$-test. ${ }^{\mathrm{b}}$ Chi square test. 'Salvage regimens: A, ETV $1.0 \mathrm{mg}$ daily; B, ETV $1.0 \mathrm{mg}$ plus ADV $10 \mathrm{mg}$ daily; C, ETV $0.5 \mathrm{mg}$ plus ADV $10 \mathrm{mg}$ daily.

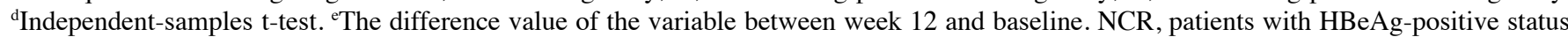
at week 104; CR, patients with HBeAg loss and HBV-DNA undetectable at week 104. ALT, alanine aminotransferase; ULN, upper limit of normal; $\mathrm{HBeAg}$, hepatitis B e antigen.

$\mathrm{HBeAg}$ levels and serum IL-21 concentration on the probability of HBeAg-decline (Table III). The different initial antiviral therapies and salvage regimens had no influence on treatment outcomes. The variable that was significant in the univariate analysis was elevated levels of serum IL-21 from baseline to week $12(\mathrm{P}=0.03)$. All variables with a $\mathrm{P}<0.10$ were included in the multivariate analysis. The variables with the strongest predictive value on $\mathrm{HBeAg}$ decline included the elevated levels of IL-21 over the initial 12 weeks of treatment $\left(\mathrm{R}^{2}=0.20\right)$ and the ALT levels at week $24\left(\mathrm{R}^{2}=0.21\right)$. Following adjustment for confounding factors, logistic regression analysis demonstrated that the elevation of IL-21 has an independent predictive value for the decline of HBeAg levels (odds ratio=1.137; $\mathrm{R}^{2}=0.23 ; \mathrm{P}=0.047$; Table $\mathrm{SII}$ ). A receiver operating characteristic curve was generated to assess the use of IL-21 elevation over the initial 12 weeks to predict the $\mathrm{HBeAg}$ decline at week 104 (Fig. 3D). The area under ROC curve was 0.798 (CI, 0.596-1.000; $\mathrm{P}=0.024$ ). The optimal cut-off value for IL-21 elevation over 12 weeks was $12.6 \mathrm{pg} / \mathrm{ml}$, at which the sensitivity and specificity for predicting an $\mathrm{HBeAg}$ decline were 85.7 and $76.5 \%$, respectively. Elevated levels of IL-21 at 12 weeks by $<12.6 \mathrm{pg} / \mathrm{ml}$ had a negative predictive value for HBeAg decline of $92.9 \%$.

\section{Discussion}

The present study was the first prospective longitudinal observation on serum IL-21 levels and virological markers in patients with SOR receiving ETV with or without ADV as the salvage therapy. The results indicated that the elevation of the levels of IL-21 from baseline to week 12 was significantly higher in those patients who achieved a decline of $\mathrm{HBeAg}$ at treatment week 104 and that the elevation of IL-21 levels over the initial 12 weeks of treatment had an independent effect on/was able to predict $\mathrm{HBeAg}$ decline at week 104. In the present study, the patients with SOR who presented with an apparent HBeAg decline over 104 weeks of salvage therapy were more likely to achieve HBeAg loss (the proportion of $\mathrm{HBeAg}$ loss in the ED group and NED group was $57.1 \%$ vs. $0 ; \mathrm{P}=0.003$ ) and $\mathrm{HBeAg}$ seroconversion. Therefore, the elevation of IL-21 levels at week 12 may be associated with immune response and favorable treatment outcomes of salvage therapy in patients with SOR. These results are consistent with those reported in previous studies. Ma et al (12) observed that high serum levels of IL-21 following 12 weeks of antiviral therapy predicted $\mathrm{HBeAg}$ seroconversion in patients with CHB. Li et al (14) demonstrated that the HBV-specific circulating chemokine $\mathrm{C}-\mathrm{X}-\mathrm{C}$ motif receptor $5(\mathrm{CXCR} 5)^{+} \mathrm{CD}^{+}{ }^{+} \mathrm{T}$ cells (Tfh cells) were able to promote anti-HBe production by autologous $\mathrm{B}$ cells via IL-21 in order to benefit HBeAg seroconversion. All of these results implied that the upregulation of serum IL-21 levels during the early stage of antiviral treatment probably had a positive correlation with the immune response required for $\mathrm{HBeAg}$ seroconversion and favorable clinical outcomes. The study by $\mathrm{Wu}$ et al (20) further highlighted 
Table III. Univariate analysis of factors possibly associated with HBeAg-decline.

\begin{tabular}{|c|c|c|c|}
\hline Variable/treatment week & $\mathrm{ED}(\mathrm{n}=7)$ & $\operatorname{NED}(n=17)$ & P-value \\
\hline Age (years) ${ }^{\mathrm{a}}$ & $31.0(28.4-48.8)$ & $28.0(23.6-43.2)$ & 0.354 \\
\hline Male sex $(n, \%)^{b}$ & $3(42.9)$ & $12(70.6)$ & 0.356 \\
\hline Initial antiviral therapy $(\mathrm{ADV} / \mathrm{LdT} / \mathrm{ETV})^{\mathrm{b}}$ & $7 / 1 / 0$ & $15 / 1 / 1$ & 1.000 \\
\hline Salvage regimen $(\mathrm{A} / \mathrm{B} / \mathrm{C})^{\mathrm{b}, \mathrm{c}}$ & $1 / 2 / 4$ & $3 / 7 / 7$ & 0.840 \\
\hline \multicolumn{4}{|l|}{ HBV-DNA $\left(\log _{10} \mathrm{IU} / \mathrm{ml}\right)^{\mathrm{d}}$} \\
\hline 0 & $3.9(3.6-6.8)$ & $5.3(4.1-7.1)$ & 0.147 \\
\hline 12 & $2.3(1.5-2.8)$ & $2.9(1.3-4.0)$ & 0.209 \\
\hline 24 & $1.5(1.3-1.8)$ & $2.1(1.3-3.3)$ & 0.187 \\
\hline \multicolumn{4}{|l|}{$\operatorname{ALT}(\mathrm{ULN})^{\mathrm{a}}$} \\
\hline 0 & $1.4(0.6-2.7)$ & $0.8(0.5-2.6)$ & 0.619 \\
\hline 12 & $1.1(0.5-2.2)$ & $0.8(0.4-1.5)$ & 0.349 \\
\hline 24 & $0.9(0.5-1.4)$ & $0.6(0.4-0.8)$ & 0.087 \\
\hline Baseline $\mathrm{HBeAg}\left(\log _{10} \mathrm{~S} / \mathrm{CO}\right)^{\mathrm{a}}$ & $1.6(0.04-3.0)$ & $2.7(0.9-3.1)$ & 0.418 \\
\hline \multicolumn{4}{|l|}{ IL-21 $(\mathrm{pg} / \mathrm{ml})^{\mathrm{d}}$} \\
\hline 0 & $44.9 \pm 13.0$ & $52.6 \pm 11.6$ & 0.169 \\
\hline 12 & $60.6 \pm 11.8$ & $55.7 \pm 11.0$ & 0.340 \\
\hline 24 & $71.2 \pm 19.3$ & $63.0 \pm 15.1$ & 0.275 \\
\hline $12-0^{\mathrm{e}}$ & $15.6 \pm 8.3$ & $3.1 \pm 13.2$ & 0.030 \\
\hline
\end{tabular}

that IL-10 and IL-12 were predictors of early spontaneous $\mathrm{HBeAg}$ seroconversion. These studies suggested the utility of serum IL levels for predicting disease outcomes in the clinic.

However, the results of the present study indicated no association between IL-21 levels at treatment week 12 and the clinical outcomes of $\mathrm{HBeAg}$ loss at treatment week 104, which differed from the study of Ma et al (12). Although this discrepancy may be attributed to the small sample size of the present study, it is more likely due to the unique clinical features of the patients with SOR to antiviral treatment. That these patients may have exhibited differences in their immune status, since they had a treatment history. For instance, the patients with SOR in the present study exhibited relatively lower levels of HBV-DNA, ALT and $\mathrm{HBeAg}$ compared with those of the treatment-naïve patients in the study of Ma et al (12). While the conclusions of the present studies are not in line with those of the above study, the data provide important clinical information for the management of patients with SOR. The present study suggested that unlike those in the treatment-naïve population, serum IL-21 levels in patients with SOR may not be used as a predictor of HBeAg loss. The present results expanded the current knowledge regarding patients with SOR receiving salvage antiviral therapy. Giarda et al (21) demonstrated no association between serum IL-21 levels and HBeAg seroconversion among patients with $\mathrm{HBV}$ and HIV coinfection following antiviral treatment for both diseases. IL-21 levels were considerably low during $\mathrm{HBV}$-active antiretroviral therapy and it was speculated that the immune response associated with IL-21 was not the driving factor for $\mathrm{HBeAg}$ seroconversion.

IL-21 is a cytokine that is mainly secreted by activated $\mathrm{CD}^{+}{ }^{+} \mathrm{T}$ cells and natural killer $\mathrm{T}$ cells. Previous studies have indicated that IL-21 is able to promote the proliferation of $\mathrm{HBcAg}$-specific IFN- $\gamma^{+} \mathrm{CD} 8^{+} \mathrm{T}$ cells, which is involved in the control of HBV replication $(10,11,22)$. In addition, IL-21 is able to directly or, via $\mathrm{CXCR}^{+} \mathrm{CD} 4^{+}$ $\mathrm{T}$ cells ( $\mathrm{Tfh}$ cells), indirectly contribute to the production of anti-HBe by B cells, which is associated with $\mathrm{HBeAg}$ seroconversion $(14,23,24)$. Earlier studies have suggested discrepancies in the correlation between serum IL-21 levels and HBV DNA, HBeAg and ALT levels (11,12,15,22,25-27). The present study indicated that the serum IL-21 levels at baseline exhibited no correlation with serum HBV DNA or serum ALT levels. However, IL-21 levels may exhibit a negative correlation with serum $\mathrm{HBeAg}$ levels $\left(\mathrm{r}_{\mathrm{s}}=-0.386\right.$, $\mathrm{P}=0.062$ ). These data support the notion that IL-21 may have no direct involvement in the control of HBV replication and liver inflammation, but they indicate the possibility that IL-21 is associated with the immune response to HBV. Such a response may contribute to an $\mathrm{HBeAg}$ level decline and $\mathrm{HBeAg}$ seroconversion.

Serum IL-21 levels were upregulated from baseline to week 36 of the salvage treatment, notably in the first 12 weeks of treatment. During this period, serum HBV-DNA levels 
declined significantly and serum ALT levels normalized in the majority of the study subjects. The upregulation of IL-21 levels may suggest that the defective HBV-specific immune response in patients with SOR is partially recovered. Following week 36, the immune response to HBV was gradually reduced, as the antiviral drugs further suppressed HBV replication, resulting in a gradual decrease of the IL-21 concentration to the baseline levels.

Although the present study was the first to investigate the association between serum IL-21 levels and treatment outcomes in a prospective cohort of patients with SOR, certain limitations should be highlighted. IL-21 levels were only measured in serum extracted from the peripheral blood, which may not completely reflect IL-21 levels and immune reactions in the liver. Future studies investigating IL-21 levels in liver tissues are required. In addition, the sample size was small and additional studies with a larger number of subjects are required to confirm the present results. Finally, only a limited number of parameters were assessed and it was not possible to measure T-cell specific immune responses to HBV. As the immune reaction to $\mathrm{HBV}$ involves complex interactions between varieties of immune cells and a broad range of cytokines, further studies should involve more cytokines associated with immune response. Furthermore, the studies should be conducted at the immune cellular level. The mechanism of the role of IL-21 in the immune response to HBV requires further research.

In conclusion, serum IL-21 levels at treatment week 12 were associated with a decline in $\mathrm{HBeAg}$ levels at treatment week 104 in patients with SOR receiving antiviral treatment of ETV with or without ADV. Elevated serum levels of IL-21 at treatment week 12 were an independent predictor for $\mathrm{HBeAg}$ decline at treatment week 104.

\section{Acknowledgements}

Not applicable.

\section{Funding}

The present study was supported in part by the National Science and Technology Major Project of China (grant no. 2018ZX10302206-003-006), Beijing Hospitals Authority Clinical Medicine Development of Special Funding Support (grant no. XMLX201837) and the Digestive Medical Coordinated Development Center of Beijing Hospitals Authority (grant no. XXT26).

\section{Availability of data and materials}

The datasets used and/or analyzed during the current study are available from the corresponding author on reasonable request.

\section{Authors' contributions}

HX and SL made substantial contributions to the conception and design. YL, SJ, GY, JC, CQP and SL contributed to the acquisition, analysis and interpretation of data. YL, CQP, HX and SL were involved in drafting the manuscript and revising it critically for important intellectual content. All authors read and approved the final version of the manuscript to be published and agreed to be accountable for all aspects of the work.

\section{Ethics approval and consent to participate}

The present study was approved by the Ethics Committee of the Beijing Ditan Hospital, Capital Medical University (Beijing, China; no. NFEC-201011-K1) and written informed consent was obtained from each patient.

\section{Patient consent for publication}

Not applicable.

\section{Competing interests}

The authors declare that they have no competing interests.

\section{References}

1. Chang JJ and Lewin SR: Immunopathogenesis of hepatitis B virus infection. Immunol Cell Biol 85: 16-23, 2007.

2. European Association for the Study of the Liver. Electronic address: easloffice@easloffice.eu; European Association for the Study of the Liver: EASL 2017 Clinical Practice Guidelines on the management of hepatitis B virus infection. J Hepatol 67: 370-398, 2017.

3. Parrish-Novak J, Dillon SR, Nelson A, Hammond A, Sprecher C, Gross JA, Johnston J, Madden K, Xu W, West J, et al: Interleukin 21 and its receptor are involved in NK cell expansion and regulation of lymphocyte function. Nature 408: 57-63, 2000.

4. Bryant VL, Ma CS, Avery DT, Li Y, Good KL, Corcoran LM, de Waal Malefyt R and Tangye SG: Cytokine-mediated regulation of human $\mathrm{B}$ cell differentiation into Ig-secreting cells: Predominant role of IL-21 produced by CXCR5+ T follicular helper cells. J Immunol 179: 8180-8190, 2007.

5. Wei L, Laurence A, Elias KM and O'Shea JJ: IL-21 is produced by Th17 cells and drives IL-17 production in a STAT3-dependent manner. J Biol Chem 282: 34605-34610, 2007.

6. Coquet JM, Kyparissoudis K, Pellicci DG, Besra G, Berzins SP, Smyth MJ and Godfrey DI: IL-21 is produced by NKT cells and modulates NKT cell activation and cytokine production. J Immunol 178: 2827-2834, 2007.

7. Spolski R and Leonard WJ: Interleukin-21: Basic biology and implications for cancer and autoimmunity. Annu Rev Immunol 26: 57-79, 2008.

8. Mantellone G, Pallone F and Macdonald TT: Interleukin-21 as a new therapeutic target for immune-mediated diseases. Trends Pharmacol Sci 30: 441-447, 2009.

9. Li HJ, Kang FB, Li BS, Yang XY, Zhang YG and Sun DX: Interleukin-21 inhibits HBV replication in vitro. Antivir Ther 20: 583-590, 2015.

10. Zhong H, Xibing G, Yaping D, Zheng W, Decai F, Xiaoye G, Hangyuan W, Dong W and Zhonghua L: Interleukin-7 in patients with chronic hepatitis B may have effect on T follicular helper cells and specific cellular immunity. Hepat Mon 16: e36068, 2016.

11. Li L, Liu M, Cheng LW, Gao XY, Fu JJ, Kong G, Feng X and Pan XC: HBcAg-specific IL-21-producing CD4+ T cells are associated with relative viral control in patients with chronic hepatitis B. Scand J Immunol 78: 439-446, 2013.

12. Ma SW, Huang X, Li YY, Tang LB, Sun XF, Jiang XT, Zhang YX, Sun J, Liu ZH, Abbott WG, et al: High serum IL-21 levels after 12 weeks of antiviral therapy predict $\mathrm{HBeAg}$ seroconversion in chronic hepatitis B. J Hepatol 56: 775-781, 2012.

13. Publicover J, Goodsell A, Nishimura S, Vilarinho S, Wang ZE, Avanesyan L, Spolski R, Leonard WJ, Cooper S and Baron JL: IL-21 is pivotal in determining age-dependent effectiveness of immune responses in a mouse model of human hepatitis B. J Clin Invest 121: 1154-1162, 2011.

14. Li Y, Ma S, Tang L, Li Y, Wang W, Huang X, Lai Q, Zhang M, Sun J, Li CK, et al: Circulating chemokine (C-X-C Motif) receptor 5(+) CD4(+) T cells benefit hepatitis $\mathrm{B}$ e antigen seroconversion through IL-21 in patients with chronic hepatitis B virus infection. Hepatology 58: 1277-286, 2013. 
15. Wu X, Su Z, Cai B, Yan L, Li Y, Feng W and Wang L: Increased circulating follicular regulatory T-like cells may play a critical role in chronic hepatitis B virus infection and disease progression. Viral Immunol 31: 379-388, 2018.

16. Chen HM, Liu HL, Yang YC, Cheng XL, Wang YF, Xing FF and Zhao YR: Serum IL-21 levels associated with chronic hepatitis B and hepatitis B-related liver failure. Exp Ther Med 7: 1013-1019, 2014.

17. Vyas AK, Sharma BC, Sarin SK and Trehanpati N: Immune correlates of hepatitis B surface antigen spontaneous seroconversion in hepatitis B e antigen negative chronic hepatitis B patients. Liver Int 38: 38-49, 2018

18. Liu X, Shen Z, Zhang H, Liang J and Lin H: Interleukin-21 is associated with early antiviral response in patients with hepatitis B e antigen-positive chronic hepatitis B and nonalcoholic fatty liver disease. J Interferon Cytokine Res 36: 367-373, 2016.

19. Lai CL, Gane E, Liaw YF, Hsu CW, Thongsawat S, Wang Y, Chen Y, Heathcote EJ, Rasenack J, Bzowej N, et al: Telbivudine versus lamivudine in patients with chronic hepatitis B. N Engl J Med 357: 2576-2588, 2007.

20. Wu JF, Wu TC, Chen CH, Ni YH, Chen HL, Hsu HY and Chang MH: Serum levels of interleukin-10 and interleukin-12 predict early, spontaneous hepatitis B virus e antigen seroconversion. Gastroenterology 138: 165-172.e1-e3, 2010

21. Giarda P, Avihingsanon A, Sasadeusz J, Audsley J, Marks P, Matthews G, Ruxrungtham K, Lewin SR and Crane M: CXCL-10, interleukin-12 and interleukin-21 are not immunological predictors of $\mathrm{HBeAg}$ seroconversion in $\mathrm{HIV}-1-\mathrm{HBV}$ coinfection following HBV-active antiretroviral therapy. Antivir Ther 19: 429-433, 2014
22. Li J, Ren W, Ma W, Zhang J, Shi J and Qin C: Interleukin-21 responses in patients with chronic hepatitis B. J Interferon Cytokine Res 35: 134-142, 2015.

23. Crotty S: Follicular helper CD4 T cells (Tfh). Annu Rev Immunol 29: 621-663, 2011.

24. Ozaki K, Spolski R, Feng CG, Qi CF, Cheng J, Sher A, Morse HC III, Liu C, Schwartzberg PL and Leonard WJ: A critical role for IL-21 in regulating immunoglobulin production. Science 298: $1630-1634,2002$.

25. Hu TT, Song XF, Lei Y, Hu HD, Ren H and Hu P: Expansion of circulating TFH cells and their associated molecules: Involvement in the immune landscape in patients with chronic HBV infection. Virol J 11: 54, 2014.

26. Pan Q, Yu Y, Tang Z, Xi M, Jiang H, Xun Y, Liu X, Liu H, Hu J and Zang G: Increased levels of IL-21 responses are associated with the severity of liver injury in patients with chronic active hepatitis B. J Viral Hepat 21: e78-e88, 2014.

27. Xing T, Xu H and Yu W: Role of T follicular helper cells and their associated molecules in the pathogenesis of chronic hepatitis B virus infection. Exp Ther Med 5: 885-889, 2013.

(i) (8) This work is licensed under a Creative Commons Attribution-NonCommercial-NoDerivatives 4.0 International (CC BY-NC-ND 4.0) License. 